This item was submitted to Loughborough's Research Repository by the author.

Items in Figshare are protected by copyright, with all rights reserved, unless otherwise indicated.

\title{
The 2017 RGS-IBG chair's theme: decolonising geographical knowledges, or reproducing coloniality?
}

PLEASE CITE THE PUBLISHED VERSION

http://dx.doi.org/10.1111/area.12371

\section{PUBLISHER}

(c) Wiley

\section{VERSION}

AM (Accepted Manuscript)

\section{PUBLISHER STATEMENT}

This is the peer reviewed version of the following article: Esson, James; Noxolo, Patricia; Baxter, Richard; Daley, Patricia; Byron, Margaret (2019): The 2017 RGS-IBG chair's theme: decolonising geographical knowledges, or reproducing coloniality? Area, 49(3), pp. 384-388, which has been published in final form at https://doi.org/10.1111/area.12371. This article may be used for non-commercial purposes in accordance with Wiley Terms and Conditions for Use of Self-Archived Versions

\section{LICENCE}

CC BY-NC-ND 4.0

\section{REPOSITORY RECORD}

Esson, James, Patricia Noxolo, Richard Baxter, Patricia Daley, and Margaret Byron. 2019. "The 2017 RGSIBG Chair's Theme: Decolonising Geographical Knowledges, or Reproducing Coloniality?”. figshare. https://hdl.handle.net/2134/25473. 
The 2017 RGS-IBG chair's theme: decolonising geographical knowledges, or reproducing coloniality?

\author{
*James Esson \\ Department of Geography, Loughborough University, Loughborough, LE11 \\ 3TU, UK j.esson@lboro.ac.uk \\ ${ }^{*}$ Corresponding author
}

Richard Baxter

School of Geography, Queen Mary University of London, London, E1 4NS, UK

r.baxter@qmul.ac.uk

Patricia Noxolo

Department of Geography, University of Birmingham, Birmingham, B15 2TT, UK p.e.p.noxolo@bham.ac.uk

\title{
Patricia Daley
}

School of Geography and the Environment, University of Oxford, Oxford, OX1 3QY, UK patricia.daley@ouce.ox.ac.uk

Margaret Byron

Department of Geography, University of Leicester, Leicester, LE1 7RH, UK mb416@le.ac.uk 


\section{Abstract}

The theme for the chair's plenaries at the 2017 Royal Geographical Society (RGS) with the Institute of British Geographers (IBG) Annual Conference is 'Decolonising geographical knowledges: opening geography out to the world'. This commentary explains why this pursuit of critical consciousness via decolonial thinking could do more harm than good. We show how the emphasis on decolonising geographical knowledges rather than structures, institutions and praxis reproduces coloniality, because it recenteres nonIndigenous, white and otherwise privileged groups in the global architecture of knowledge production. It is argued that an effective decolonial movement within geography must recognise the intersectionality of indigeneity and race, and necessitates that the terms on which the discipline starts debates about decolonisation and decoloniality are determined by those racialized as Indigenous and non-white by coloniality.

\section{Key words:}

Coloniality; Decolonisation; Geographical Knowledges; Indigeneity; Racism; Whiteness 


\section{Introduction}

The theme for the chair's plenaries at the 2017 Royal Geographical Society (RGS) with the Institute of British Geographers (IBG) Annual Conference is 'Decolonising geographical knowledges: opening geography out to the world'. According to the Chair's abstract for the conference, the event will form 'part of an agenda to 'query implicitly universal claims to knowledges associated with the west, and further interrogate how such knowledges continue to marginalise and discount places, people and knowledges across the world' (visible at RGS-IBG, 2017). In this paper, we aim to explain why this pursuit of critical consciousness via a decolonial approach could do more harm than good, in a discipline that may not be ready to, or even capable of, responding to the challenge of decolonisation. To be clear, this commentary is a call to confront structural issues within the discipline. We are not seeking to vilify or discredit individuals or groups who are striving for social justice and that have devoted their careers to educating themselves and others to be critical of settler colonialism and coloniality. By coloniality, we mean the "long-standing patterns of power that emerged as a result of colonialism, but that define culture, labour, intersubjective relations, and knowledge production well beyond the strict limits of colonial administrations" (Maldonaldo-Torres 2007: 243).

We are intervening at this conjuncture because decolonisation entails the removal of ongoing colonial domination, thereby connecting moves to dismantle the racist social classification of the world population under Eurocentric world power (see Mignolo 2008; Ndlovu-Gatsheni 2015) to 
Indigenous-led demands for radical restructuring of land, resources and wealth globally (see Tuck and Yang 2012). The focus on decolonising knowledges should be positioned as a means to this end, not as an end in itself. We argue that the current emphasis on decolonising geographical knowledges rather than structures, institutions and praxis, and the disingenuous phrase 'opening geography out to the world' (as if geographers, and indeed the RGS, had never been involved in the exploration, colonisation and continuing exploitation of the world and its resources) dilutes decolonisation and decoloniality's transformative potential, while concealing oppressive structures in the discipline and recentering nonIndigenous, white and otherwise privileged groups in the global architecture of knowledge production. To prevent this, the discipline needs to ensure that the terms on which geographers start debates about decolonisation and decoloniality are determined by those on the margins who have been racialized as Indigenous and non-white by coloniality.

\section{Decolonisation is not a metaphor}

Decolonisation is fundamentally 'unsettling', it has a peculiar resonance in former settler colonies (Tuck and Yang, 2012), but globally decolonisation seeks to topple the coloniality of power and its constitutive matrix (Quijano 2000: 533). Decolonial movements organised by activists have existed in the UK and across the globe for some time. Accordingly, decolonisation is a politics of radical change that does not belong to the academy, and is not a 'theme' that can be taken up for the three days of the conference and then 
put down. Therefore, while we recognise that the cultivation of critical consciousness as articulated in the conference's call to 'decolonise geographical knowledges' is important, we propose that critical consciousness cannot be the focus of genuine decolonial moves, as without activism we will not tackle imperialist-white supremacist-capitalist-patriarchy (hooks 2004) or bring about the radical restructuring of land, resources and wealth globally. There are those who take these points further, and argue that the front-loading of critical consciousness building by academics undermines and dilutes decolonial movements, as it is a prime example of what Tuck and Yang (2012) call 'moves to innocence': strategies and positionings that aim to relieve those who benefit from coloniality of feelings of guilt or complicity, without having to change their privileged position at all.

A key first step in preventing the RGS-IBG conference becoming a collective move to innocence will be for geographers to take up Rivera Cusicanqui's call for an actively "decolonizing practice" (2012 p.100) in academic work that goes deeper than vocabulary. Why? Because 'our institutions must undergo a process of decolonization both of knowledge and of the university as an institution' (Mbembe, 2016: 11). We envision this taking place as part of a decolonial agenda that steps away from a fixation with epistemology, and towards praxis that both reveals and seeks to address how forms of violence and 'microagressions' experienced by Indigenous and racialised groups within the academy and in everyday life are both normalized and officially sanctioned by institutional arrangements (see also Mbembe 2016; Tate 2014; Tejeda et al. 2003; Todd 2016). In the academy specifically, Mahtani (2014) argues that racialised hierarchies produce 'emotionally toxic 
material spaces' for non-white and Indigenous geographers, which are made invisible by liberal discourse. Crucially, given the demographic makeup of the discipline, taking up Rivera Cusicanqui's call would require an acknowledgement of white privilege and racism in the past and present, as the intersectionality of indigeneity and race, and the adoption of an antiracist standpoint are prominent in the work of pioneering decolonial scholars (see Aime Cesaire, Frantz Fanon, Walter Mignolo, Anibal Quijano, Ngũgĩ wa Thiong'o and Sylvia Wynter).

This point about privilege and racism is particularly salient because it is notable that neither race, nor (beyond a broad reference to 'Indigenous knowledges') indigeneity were mentioned in the original abstract for the 2017 conference. We note the subsequent tweaks to the conference webpage and the demographic of plenary speakers came soon after interventions by nonwhite and Indigenous geographers. Likewise, the original abstract, conference webpage and numerous calls for sessions fail to encourage a substantive reflection on the discipline's implication in the historical establishment of colonialism and the reproduction of coloniality today. The decolonisation of geographical knowledges cannot take place while racist and colonialist structures inherited from the discipline's colonial and imperial past are maintained.

We therefore call on geographers, and key geographical institutions such as the RGS-IBG, to recognise oppressive racialised structures in the discipline and demonstrate a commitment to anti-racism as a prerequisite to embarking on decolonial moves within the discipline. This has to be an overt feature for reasons mentioned above, but also because the social circulation 
of race as a social force is often supported by well-intentioned race fictions held by the dominant racial group, including those who see themselves as liberal progressives. One of these fictions is that if a person does not hold racist views, as normatively defined, then they are not involved in perpetuating racial inequality and therefore do not have to adopt an explicitly anti-racist position (Bonilla Silva cited in Walter and Butler, 2013).

To be clear, we are not asking for scholars and activists racialised as nonwhite and Indigenous to be offered more socially equitable participation in existing colonialist and racist structures of domination and exploitation (such a move, as Tuck and Yang, 2012: 28, point out, is incommensurable with decolonisation). We are insisting that the dismantling of these structures be made an explicit feature of any decolonial agenda set out at or around the conference. In the section that follows, we explain why a failure to engage with the ideas put forward above and to address our concerns about the conference will reproduce coloniality within the discipline.

\section{Reproducing Coloniality?}

Most immediately, information is needed on the longer term decolonial moves that have already taken place and will take place within UK geography: practical engagements with and by multiple decolonial actors need to be well-publicised before, during and after the conference. Without this information, a cohort of Indigenous and non-white scholars and activists will continue to view the forthcoming RGS-IBG conference with a degree of scepticism. There are two key reasons for this. First, although the abstract 
asserts that "debates around decolonizing geographical knowledges have become increasingly important among teachers, activists and academics during the past decade" (RGS-IBG, 2017), the majority of geographers have remained peripheral to contemporary decolonial struggles, including high profile cases such as the Rhodes Must Fall campaigns in Oxford and South Africa, but also the vibrant set of activities taking place beyond the academy here in the UK. An example of the latter was Decoloniality London, which established a teaching programme on decolonial thought and praxis outside of higher education. Second, the study of decolonisation within geography and allied disciplines does not occur outside the politics of the academy, whereby some stand to gain as gatekeepers and as privileged voices. The role of whiteness in these norms and practices needs interrogation, as Indigenous scholars and those racialised as non-white are already subject to coloniality and struggle to maintain a presence within the discipline (see Todd, 2016; Peake and Kobayashi, 2000).

The concerns above resonate with Rivera Cusicanqui's (2012: 95-7) assertion that in powerful academic contexts dominated by non-Indigenous and white western scholars, where Indigenous (and thereby non-white) people are not central and do not call the shots, a "logocentric and nominalist version" of decolonial approaches gets recirculated and marketed (Rivera Cusicanqui 2012: 102). Tuck and Yang (2012) reiterate this point, and note how the recent proliferation of decolonial language by nonIndigenous and white academics can reproduce coloniality via the reaffirmation of white privilege, i.e. the 'largely unspoken advantage that accrues by a social structural system normed on White people's 
experiences, values, culture and perceptions' (Walter and Butler 2013: 401). Todd (2017) illustrates these points by describing how in the academy, 'Indigenous bodies, stories, knowledge, and 'contacts' ('informants', 'participants' or 'interlocutors') act as a kind of currency or capital that is concentrated in the hands of non-Indigenous scholars and administrators. Therefore, overwhelmingly, it is still white people who control the flow of this knowledge and the parameters of these relationships'.

To be clear, it is still possible and perhaps even necessary to talk about Indigenous worldviews from the 'outside', and to engage in dialogue, but without an Indigenous and non-white power base there is a real risk that, "decolonization becomes a domesticated industry of ideas" (Sium et al. 2012: IV) that is removed from the acutely situated logics of Indigenous and non-white activism and scholarship. Moreover, coloniality's hierarchy of primarily white racial superiority and Indigenous and non-white inferiority are rendered invisible and left unscathed. This further creates a scenario whereby, in seeking to 'decolonize geographical knowledges and open geography out to the world', geographers run the risk of speaking not for but instead of those not only willing and able, but eager and equipped, to speak for themselves. (Bob Geldof, a recent recipient of an RGS Patron's medal, is a contemporary example of this in action; see Daley 2005 for a detailed discussion).

There is therefore a real danger that the conference will lead to further subjection, as some Indigenous and non-white scholars intend to avoid a gathering that ignores and reproduces coloniality, while those who are planning to attend are marginalised and feel they run the risk of co-option. 
Some non-white and Indigenous geographers have already been marginalised in the run up to the conference and have not felt able to contribute to the organisation of the event. It is therefore imperative that the conference organisers, the RGS-IBG and attendees consider how they are going to address the further oppression of Indigenous and non-white scholars, and mitigate the trifold issues of co-option, disempowerment of decolonial thinking and reaffirmation of white privilege that may occur because of the conference.

\section{Conclusions}

Decolonisation is a radical challenge to 'unsettle' the architecture of privilege (Tuck and Yang 2012: 3). It must involve the decolonisation of mind and revolutionary action (Fanon 1967). The first RGS-IBG conference on decolonisation therefore provided an opportunity to establish geography as a more progressive discipline. Instead, the conference reflects ongoing structural problems of race and indigeneity in higher education and society more generally. An effective decolonial movement in geography needs to focus on revealing problems of coloniality within the discipline and beyond, and attempt to destabilise the architecture of white and non-Indigenous privilege (see Shilliam, 2015). Beginning debates about decolonisation and decoloniality with those racialized as Indigenous and non-white is a fundamental starting point for such a move. To this end, we recommend that during the conference and in the following months both geographers and key geographical institutions such as the RGS-IBG engage in genuine reflection 
about the (non)status of race and indigeneity in the discipline. This should result in changes that disrupt established systems of privilege, for example in relation to the theme of this paper, the politics of Chair nomination, election and conference organisation.

By choosing this particular theme, the RGS-IBG has located geography within a radical agenda around decolonisation as both knowledge and practice. The authors of this commentary are trying to remain optimistic that the 2017 conference will provide tangible evidence that the discipline is indeed ready to, and capable of, responding to the challenge of decolonisation. This sense of optimism should not be read as a passive yearning for an abstract idyllic future but rather a signal of our discontent in the present, as articulated above, alongside a belief 'in the creative possibilities that become available when we recognise each other (and each 'Other') as we come together on the basis of a commitment to decolonization' (Gaztambide-Fernández, 2012: 61 emphasis in original). It remains to be seen whether geographers and key institutions will take up this opportunity and genuinely "dare to imagine the unimaginable" (Pezzani, 2010: 78). We hope we will because as noted by Sylvia Wynter, in the challenge to defeat coloniality 'the buck stops with us' (Wynter, 2003: 331).

\section{Acknowledgements:}

We wish to acknowledge all the members of the RACE working group, as well as all the other non-white and indigenous colleagues, friends and 
activists who have dialogued with us in the preparation of this short commentary. 


\section{References:}

Daley P 2005 Bob Geldof and the Livingstone connection: Africa not yet saved? Pambazuka News Issue 214 http://www.pambazuka.org/governance/bob-geldof-and-livingstoneconnection-africa-not-yet-saved Accessed 31 May 2017

Fanon F 1967 Black skin, white masks New York Grove Press

Gaztambide-Fernández R A 2012 Decolonization and the pedagogy of solidarity Decolonization: Indigeneity, Education \& Society 1(1) 41-67

hooks b 2004 We real cool: Black men and masculinity New York and London Routledge

Mahtani M 2014 Toxic geographies: absences in critical race thought and practice in social and cultural geography Social and Cultural Geography 15 359-367

Maldonaldo-Torres N 2007 On the coloniality of being: Contributions to the development of a concept Cultural studies 21(2-3) 240-270

Mbembe A J 2016 Decolonizing the university: New directions Arts and Humanities in Higher Education 15(1) 29-45

Mignolo W D 2008 Racism as we sense it today Publications of the Modern Languages Association of America123(5) 1737-1742

Ndlovu-Gatsheni S J 2015 Decoloniality as the Future of Africa History Compass 13(10) 485-496

Peake $L$ and Kobayashi A 2002 Policies and practices for an antiracist geography at the millennium The professional geographer 54(1) 50-61

Pezzani L 2010 Decolonizing architecture, or, 'How to inhabit your enemy's house?' Contemporary Practices VII: 72-9

Quijano A 2000 Coloniality of power, Eurocentrism, and Latin America Nepantla 1: 533-80 
RGS-IBG 2017 Chair's theme and plenary lectures

http://www.rgs.org/WhatsOn/ConferencesAndSeminars/Annual+International +Conference/Conference+theme.htm Accessed 31 May 2017

Rivera Cusicanqui S R 2012 Ch'ixinakax utxiwa: A Reflection on the Practices and Discourses of Decolonization South Atlantic Quarterly 111(1) 95-109

Shilliam R 2015 Black Academia: The Doors Have Been Opened but the Architecture Remains the Same in Alexander $\mathbf{C}$ and Arday $\mathbf{J}$ (eds) Aiming Higher: Race, Inequality and Diversity in the Academy London: Runnymede 32-35

Sium A Desai C and Ritskes E 2012 Towards the 'tangible unknown': Decolonization and the Indigenous future Decolonization: Indigeneity, Education \& Society 1(1) 1-XIII

Tate S A 2014 Racial affective economies, disalienation and 'race made ordinary' Ethnic and Racial Studies 37(13) 2475-2490

Tejeda C Espinoza M and Gutierrez 2003 Toward a decolonizing pedagogy: Social justice reconsidered in Trifonas $\mathbf{P}$ (ed) Pedagogies of difference: Rethinking education for social change Routledge New York and London 10-40

Todd Z 2016 An Indigenous feminist's take on the ontological turn:'Ontology' is just another word for colonialism Journal of Historical Sociology 29(1) 4-22

Todd Z 2017 Indigenous stories, knowledge, legal traditions, ontologies, epistemologies as unceded territory (or: Hands Off of Our Teachings) (https://zoestodd.com/2017/04/27/indigenous-stories-knowledge-legaltraditions-ontologies-epistemologies-as-unceded-territory-or-hands-off-ofour-teachings/) Accessed 310/05/2017

Tuck E and Yang K W 2012 Decolonization is not a metaphor Decolonization: Indigeneity, Education \& Society 1(1) 1-40 
Walter M and Butler K 2013 Teaching race to teach Indigeneity Journal of Sociology 49(4) 397-410

Wynter S 2003 Unsettling the coloniality of being/power/truth/freedom:

Towards the human, after man, its overrepresentation--An argument The New Centennial Review 3(3) 257-337 